ELORE (ISSN 1456-3010), vol. $12-1 / 2005$.

Julkaisija: Suomen Kansantietouden Tutkijain Seura ry. Taitto: Jukka Talve.

[http://cc.joensuu.fi/ /oristi/1_05/ira1_05.pdf]

\title{
KIRJA-ARVIO:
}

\section{AlKoHolilla identiteettiä}

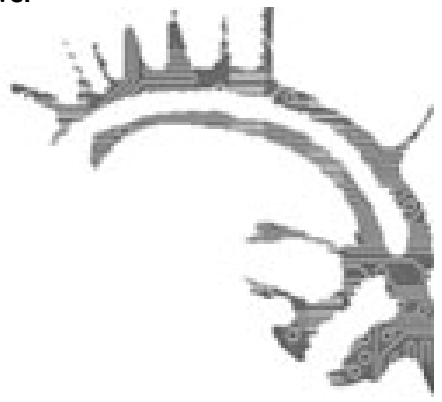

Hanna Kunsi 2003: Viinistä vapautta. Alkoholi, hallinta ja identiteetti 1960-luvun Suomessa. Helsinki: Suomalaisen Kirjallisunden Seura. 414 sivua.

Annamari Iranto

Hanna Kuusi määrittelee yhteiskuntahistoriallisen väitöskirjansa keskeiseksi tutkimuskysymykseksi alkoholin, hallinnan ja identiteetin välisen kolmiyhteyden. Hän tarkastelee 1960-lukua "muuntuneen hallintalogiikan näkökulmasta" eli lupaa selvittää, miten käskyjen ja kieltojen yhteiskunnasta pyrittiin liberaalin järjestyksen yhteiskuntaan, ihmisten käyttäytymiseen vapaaehtoisesti tietyllä tavalla.

Hallintalogiikan muuntumista tarkastellaan alkoholikulttuurin ja -politiikan kautta. Höllentynyt kuri, hallinnan siirtyminen yksilölle itselleen sekä alkoholin uudet käyttöarvot identiteettivaikutuksineen muodostavat yhdessä Kuusen tutkiman ilmiön. Johdannon mukaan tutkimus on myös "alkoholipoliittisen puheavaruuden" muutoksen tarkastelua sekä tutkimusta siitä, millaisia "vapauden käytäntöjä" uusi alkoholipolitiikka tuotti. Tutkimuksen tarkoitus on Kuusen mukaan myös valaista 1960-luvun kulttuurista muutosta laajemmin kuin vain alkoholikulttuurin osalta.

Tutkimus on moniaineistoinen ja lähdemateriaalia on erittäin paljon. Ensisijaisiksi lähteikseen Kuusi määrittelee Alkoholiliikkeen julkaiseman Alkobolipolitiik.ka-aikakauskirjan vuosilta 1958-1974, aikalaistutkimuksen ja joukon suomalaisia kokoillan elokuvia vuosilta 1961-1970. Keskeistä aineistoa ovat lisäksi raittiusliikkeen julkaisema aikakauskirja Alkobolikysymys (1958-1974), vuonna 1968 käyty valtiopäiväkeskustelu alkoholilain uudistamisesta, kokoelma iskelmäsanoituksia, 34 naiskirjailijan esikoisromaania (niin ikään vuosilta 1961-1970) sekä Eeva-Liisa Mannerin näytelmä Uuden vuoden yö. Kuusen lähteinä on myös yhteensä viisi kahden naistenlehden vuosikertaa sekä mittava määrä muuta kirjallista materiaalia.

Rakenteellisesti kirja on jaettu neljään osaan, joiden otsikot ovat Lähtökohdat, Hallinta, Identiteetti ja kulttuurivarannot sekä Positiot. Näitä täydentävät yhteenveto sekä väitöskirjaa onnistuneesti runollistavat lyhyet prologi ja epilogi. Tutkimus on tehty diskursiivisella otteella, ja sen teoreettisena viitekehyksenä ovat Michel Foucault'n pohdinnat yhteiskunnan toimintalogiikoista eli lähinnä siitä, miten val- 
ta tuottaa elämäämme itsestäänselvyydet, totuuksina ja normaalina pidetyn. Kuusen omin johdanto-osan päättävin sanoin tarkoituksena on "erityyppisistä tarkastelukulmista valottaa lähihistoriaan kuuluvia ilmiöitä ja sitä kautta [..] avata uusia näkökulmia siihen, miten me olemme tulleet tällaisiksi kuin olemme".

\section{YHTEISKUNNALLINEN TAUSTA}

Lähtökohdat-osiossa Kuusi tarkastelee ensin tiiviisti mutta silti perusteellisesti tutkimusajankohdan yhteiskunnallista rakennemuutosta. Kirjatuiksi tulevat niin elinkeinorakenteen, elintason, koulutuksen kuin työelämänkin muutokset, jotka tietysti ovat varsin tuttua asiaa. Kiinnostavinta osiossa onkin lyhyt pohdinta siitä, milloin muutoksessa on olennaisinta vauhti, milloin suhteellinen ja milloin taas absoluuttinen muutos, kun tarkastelussa on muutoksen merkitys yksilön kokemuksena.

Myös alkoholipoliittisen ilmaston muuttuminen pohjustetaan perusteellisesti, ehkäpä turhankin yksityiskohtaisesti. Tosin tekstiä kummallisesta "ostajaintarkkailujärjestelmästä" ja uuden alkoholilain säätämisen pitkästä ja mutkikkaasta tiestä on hauskakin lukea. Tässä yhteydessä kuitataan vain lyhyellä maininnalla kiinnostava aikakautta kuvaava ilmiö: kuten uuden alkoholilain valmistelussakin näkyi, poliittisessa päätöksenteossa alettiin antaa yhä enemmän painoarvoa tutkimustiedolle. Asia tulee uudelleen esiin Hallinta-osiossa, oluen vapautusta ja nuorison alkoholinkäyttöä koskevien keskustelujen tarkastelussa sekä tutkimuksen merkitystä ja tätä kehitystä erikseen valottavassa luvussa.

Kun uusi laki lukuisten komiteoiden ja valiokuntien mietintöjen jälkeen saatiin voimaan vuoden 1969 alussa, muuttui alkoholin kulutus selvästi, niin määrällisesti kuin juomaryhmittäinkin tarkasteltuna - osaksi sen vuoksi, että alkoholilaki lieventyi selvästi valmistelun pitkittyessä. Lyhyt referaatti Klaus Mäkelän tutkimuksesta kertoo lisää ajan hengestä: vapaamielinen ilmasto paitsi lisäsi kulutuksen määrä, myös loi uusia alkoholin käyttötapoja. Kokonaisuudessaan Lähtökohdatosio onnistuukin herättämään kiinnostuksen lukea lisää siitä, miksi ja miten alkoholipolitiikka ja -kulttuuri muuttuivat.

Hallinta-osion alussa Kuusi esittelee tutkimuksensa teoreettisen viitekehyksen, joka rakentuu Michel Foucault'n pohdinnoille vallan keinoista muokata ihmiset valtion kannalta sopiviksi, itseään kontrolloiviksi ja hallitseviksi kansalaisiksi. Kuusi käyttää Foucault'n käsitteestä suomennosta hallintalogïkeka, koska se kertoo hänen mielestään parhaiten sen, että "kyseessä on tiedon ja käytäntöjen muodostama monimutkainen kokonaisuus, joka ei rajoitu vain valtionhallintoon". Hallintateorian keskeiset auktoriteetit ovat Michel Foucault ja Nikolas Rose. Heidän ajatuksensa hallinnasta ja vapaudesta yksilöiden - eli näiden identiteettien muovaajina haastavat kiehtovalla tavalla pohtimaan yksilön roolia kansalaisena ja innostavat ajatuksiin käyttää teorioita myös toisenlaisissa tutkimusasetelmissa. 


\section{ALKOHOLILLA IDENTITEETTIÄ}

Hahmotellessaan kuvaa alkoholipolitiikan hallintamuotojen muutoksesta Kuusi luo katsauksen varhaiseen sosiaalitutkimukseen ja sen ongelmiin sekä kertaa kiehtovaa tarinaa käsitteen suomalainen vïnapää synnystä maassa, jossa alkoholin kulutus oli Euroopan alhaisimpia. Asia lienee tuttua monelle, etenkin Satu Apon tutkimuksen Viinan voima lukeneille, mutta Kuusi käsittelee kansallista juomatapakeskustelua jonkin verran laajemmin kuin Apo. Peräti hurmaavaa on lukea Alkoholiliikkeen ponnisteluista juurruttaa eurooppalainen humalaton (?) juomatapa tähän sivistymättömään kansaan, jonka suuri tragedia oli - ja taitaa yhä olla - ryyppääminen "peikkomaisella pauhinalla" hilpeän seurustelun sijaan. Apuna valistuksessa olivat niin omien moitiskelu kuin ihannoivat matkakuvaukset sivistyksen pariin tehdyistä retkistä; kuvauksia paremmasta ilmestyi ensin Alkoholipolitiikka-lehdessä ja sittemmin lähinnä liikkeen asiakaslehdessä Viinipostissa. Hallintalogiikan kannalta tarkasteltuna vallalla oli häpeään pohjaava autoritaarinen malli, jossa ostajaa tarkkailtiin ja kauppaa tehtiin virastomaisessa ilmapiirissä. Ongelma muodostui, kun tutkimukset selvittivät, ettei päihtymys ollutkaan suomalaisten mielestä häpeällistä. Strategiaa oli muutettava: kansa piti houkutella valitsemaan oikein, siis eurooppalaisen sivistyneesti. Niinpä entiset harmaat virastomyymälät pian yrittivät innostaa ihmisiä viinin ostoon myönteisin keinoin. Hallintalogiikaksi valittiin siis strategisesti integroiva vallankäyttö eli pyrkimys vaikuttaa ihmisten identiteettiin.

Viini-innostuksen rinnalle nousi ajatus oluen vapauttamisesta keinona vaikuttaa juomatapoihin niin, että kulutus olisi maltillista ja mietoihin juomiin painottuvaa. Samalla tavoitteena oli kuitenkin tasa-arvon lisääminen alkoholin saatavuudessa - ja mahdollisuuksissa osallistua ravintolakulttuuriin. Vielä 1960-luvun alussa ravintola oli nimittäin Kuusen mukaan "lähes tuntematon instituutio suurimmalle osalle suomalaisista".

Oluen vapautukseen liittyi perusteellinen debatti olutravintoloista. Sen lisäksi Kuusi ruotii kiistaa keskioluesta luoden samalla lyhyen - ja hauskan - katsauksen lisääntyvään olutmainontaan. Omana alalukunaan Kuusi käsittelee alkoholin vapauttamiseen liittyvää "nuorisokysymystä", jonka käsittelystä hän jo erottaa kaksi eri diskurssityyppiä, luottamuksen ja suojelun. Hallinta-osion kolmas luku päättyy koko alkoholilakiuudistuksesta käydyn keskustelun "puheavaruuden" erittelyyn. Siinä selvitetään eri diskurssityyppien luonteita ja tavoitteita. Kiinnostavasti käy ilmi, kuinka "vapauden ja vastuun puheavaruus" palveli yhtä lailla vapaamman alkoholipolitiikan ajajia kuin sen vastustajiakin.

\section{UUSI ALKOHOLIAIKA}

Vapaus koitti, alkoholinkulutusta siis selvästi lisäten. Pettymys johti strategiamuutokseen Alkoholiliikkeessä: mietojen suosiminen ei auttanut, alkoholihaittoja oli ryhdyttävä hillitsemään kokonaiskulutukseen vaikuttavin toimenpitein, siis muun muassa hintoja korottamalla ja anniskeluoikeuksia rajoittamalla. Yksilön vastuuttamisesta ei silti tarvinnut luopua. Alkoholitutkimus alkoi tuottaa tietoa riski- 
kulutuksesta, jolloin yksilölle voitiin jättää valinnan mahdollisuus. Hallintatapa siis peräti korosti yksilönvapautta. Niin sanottu kokonaiskulutusmalli hahmottui osaksi liberaalin hallintalogiikan läpimurtoa, vaikka vielä liberaalimmasta hallinnasta pitikin luopua, kun "[k]uluttajat eivät olleet osanneet käyttää vapauttaan toivotulla tavalla", kirjoittaa Kuusi.

Kuusi muistuttaa, että alkoholipoliittisten linjausten keskellä alkoholikulttuuri ikään kuin eli omaa elämäänsä. Yhteiskunnallisten muutosten vaikutus oli selvä muttei yksioikoinen, kuten Kuusi lähinnä Klaus Mäkelän ja Pekka Sulkusen tutkimuksiin viitaten osoittaa. Muutokset alkoholin - ja siitä juontuvan humalan käyttöarvoissa nousevat kiinnostavasti esiin. Kokonaisuutena kysymyksessä oli alkoholipoliittinen ja -kulttuurinen murros yhteiskunnallisen murroksen osana. Mielenkiintoista onkin Kuusen mukaan tarkastella "tilanteen kehkeytymistä", ei niinkään eritellä murroksen syy-seuraus-suhteita.

Muutoksen kuvausta Kuusi pohjustaa aloittamalla Identiteetti ja kulttuurivarannot-osion modernin ja sen osana kehittyvän uudenlaisen identiteetin selittämisellä sekä kuvaamalla identiteetin ja hallinnan suhdetta. Identiteettikriisin pohdinnasta edetään naistenlehtien neuvoihin "oikein olemisesta"; Kuusi vertaa 1950-luvun sopeutumista vaativaa diskurssia 60-lukulaiseen itsensä löytämisen diskurssiin. Median roolin identiteetin muokkaajana Kuusi tuo esiin hieman sekavasti. Hän esittelee ensin lyhyesti tutkimuksia TV:n ja elokuvan sekä varsinaisen mainonnan roolista kuluttaja-identiteettiä tuottavina tekijöinä ja viittaa sitten tutkimukseen, jonka mukaan kotimaisissa uuden aallon elokuvissa tavoitteena oli oman aikansa "tyyppien" eli samastumiskohteiden esittäminen, ei tähtikultin luominen. Seuraava alaluku siirtyy puhumaan alkoholin uusista käyttöarvoista ja juomisen terapialuonteesta. Sen jälkeen esitellään erityisesti uudenlaisen "ryyppäjäisnäytelmän” lajityypin myötä, kuinka 1960-luvun kulttuurinen murros näkyi teatterissa. Kokonaisuutena tämä osion ensimmäinen luku jää yllättävän ohueksi ja hajanaiseksi.

Kuvausta siitä, miten humala näkyy tutkimuksen elokuva-aineistossa, Kuusi taustoittaa jälleen perusteellisesti katsauksella elokuvan ja sosiaalihistorian suhteisiin ja tarjoilemalla jopa tiiviin tietopaketin maamme elokuvatuotannon historiasta. Muutaman elokuvan alkoholimaailma tulee jo tässä vaiheessa varsin perusteellisesti käsitellyksi. Luvun loppu valottaa suomalaisen uuden aallon elokuvan kehittymistä ja erittelee elokuvien tarinatyypit sen mukaan, millainen rooli alkoholilla niissä on. Osion viimeinen luku kertoo alkoholin arkistumisesta, tietyn elämäntavan kuvittamisesta arkisella alkoholinkäytöllä. Samalla Kuusi tulee ruotineeksi myös

muutaman elokuvan alkoholi- ja ihmissuhdekuvauksia sekä yhteiskunnassa vellonutta keskustelua lähiöelämän ongelmista ja sosiaalisen elämän muutoksista.

\section{0-LUKULAISET ALKOHOLIKUVAT}

Teoksen viimeinen ja samalla laajin osio Positiot lähtee liikkeelle referoiden tutkimuksia, joissa on yritetty määrittää 60-lukulaisia sukupolvena. Sen jälkeen Kuusi 


\section{ALKOHOLILLA IDENTITEETTIÄ}

erittelee perusteellisesti Käpy selän alla -elokuvan. Syntyhistoria ja vastaanotto ovat perusta elokuvan käsittämiselle identiteettitarinana; sen jälkeen käsittelyssä on se, mitä identiteetin rakentamisprosessissa tarvitaan: luontoa, psykoanalyysia ja alkoholia. Teemat tulevat esiin myös muiden elokuvien analyyseissa.

Erittelemällä aiheiden käsittelyä elokuvissa Kuusi käy läpi murroskauden ilmiöitä: maalta kaupunkiin muuttaneiden nuorten ongelmia, ylioppilasradikalismia, naisen muuttuvaa roolia. Sitä puidaan niin seksuaalisen vapautumisen kuin naisten muuttuneen alkoholinkäytönkin osalta. Naisten humala valkokankaalla ja naiskirjailijoiden kuvauksissa muodostavat omat alalukunsa, mutta elokuvien kautta esiin tulevat myös sinänsä alkoholista riippumattomat naisten yhteiskunnalliset ongelmat.

Murroskauden kulttuurituotteiden mieskuvaa Kuusi piirtää elokuvien taiteilijakuvausten avulla ja iskelmäsanoitusten maailmaa tarkastelemalla. Elokuvien taiteilijoiden identiteettiin liitettyä boheemiutta teos käsittelee myös aiemman tutkimustiedon valossa. Alkoholin ja luovuuden suhteesta tehdyn tutkimuksen referointi toimii teoksessa ikään kuin jälkikäteisenä todistuksena sille, että alkoholin liittäminen elokuvien taiteilijakuviin on ollut perusteltua.

Oman sävynsä aikakauden mieskuvaukselle antaa iskelmäsanoitusten karnevalismi. Myös luokkakapinointi ja protestihenki ovat niissä elokuvaa vahvemmin esillä. Iskelmien käsittelyn jälkeen osio palaa takaisin elokuvaan: ennen yhteenvetoa Kuusi käy vielä läpi sitä, mitkä olivat murroskauden keskeiset elementit rakennettaessa identiteettikysymystä laajempia kuvia kansakunnasta.

Tutkimus on erittäin kiinnostava ja onnistuu etenkin pyrkimyksessään kertoa uuden alkoholipolitiikan - ja muun yhteiskunnallisen murroksen - tuottamista uusista "vapauden käytännöistä". Vuosikymmenen murros tulee myös valaistuksi pelkkää alkoholikulttuuria laajemmin. Hallintalogiikan murroskin tulee näkyväksi Kuusen osoittaessa nimenomaan, miten yhteiskunta kehittyi sellaiseksi, että identiteetteihin perustuva hallinta oli mahdollista - tai sitä voitiin yrittää. Alkoholin kohdallahan hallinta ei oikein onnistunut. Toivottavasti jokin muu tutki-

mus selvittää, onko strategia muutoin katsottu päteväksi tai mitä muita strategioita joku jossakin hallitsemiseksemme toteuttaa ja suunnittelee.

\section{Annamari Iranto (FM) on Joensuun yliopiston perinteentutkija.}

